\title{
LEASING IN THE DISPOSITION OF URBAN RENEWAL LAND
}

\author{
Lyman Brownfield* and Marian S. Rosenf
}

Leasing urban renewal project land is authorized by the Housing Act in the simplest terms. ${ }^{2}$ The early legislative history of this authorization relates to the slum-clearance genesis of urban renewal and is pertinent to contemporary problems of interpretation principally because it shows how the inappropriateness of leasing as a general tool in a broadened urban renewal program was anticipated even before the program was under way in its limited slum clearance stage. ${ }^{2}$ Subsequent legislative history has been negative in character. While urban renewal has made its tremendous statutory and administrative evolution from a social welfare experiment to the basic tool for reshaping American cities to survive extensive social and technological changes, the only changes which Congress has made in connection with leasing are technical ones. They were inspired by the suggestion of bond counsel apropos of the one urban renewal lease which has been completed through the financing stage. ${ }^{3}$ The brevity of the statute and the limited legislative history necessi--

- A.B. 1934, Mount Union College; LL.B. 1937, Duke University. Former General Counsel, Housing and Home Finance Agency, and former General Counsel, Federal Housing Administration, Washington, D.C. Member of the District of Columbia and Ohio bars.

+A.B. 1952, University of Miami; LL.B. 1954, University of Houston. Formerly Office of General Counsel, Housing and Home Finance Agency, Washington, D.C. Member of the District of Columbia, Florida, and Texas bars.

${ }^{2}$ Section 105 (b) of the Housing Act of 1949 , as amended, provides as follows: "(b) When real property acquired or held by the local public agency in coninection with the project is sold or leased, thepurchaser or lessees and their assignees shall be obligated ...." 63 Stat. 416, as amended, 70 Stat. 1097 (1956), 42 U.S.C. 5 1455(b) (1958).

Section 110 of the Housing Act of 1949 , as amended, which relates to "Definitions," provides, in subsection (c) (4): "(4) disposition of any property acquired in the urban renewal area (including sale, initial leasing or retention by the local public agency itself) at its fair value for uses in aecordance with the urban renewal plan ...." 63 Stat. 420, as amended, 7 I Stat. 300 (1957), 42 U.S.C. 5 1460(c)(4) (I958).

See Foard \& Fefferman, Federal Urban Renewal Legislation, 25 Law \& Conteap. Pros. 635 (1960).

'Section ro2(a) of the Housing Act of 1949, as amended by 5402 (a) of the Housing Act of 1959 , substituted the term "for such purposes" in lieu of "as part of the gross project cost." 63 Stat. 414 , 2s. amended, 73 Stat. 654 (1959), 42 U.S.C. 5 1452(a) (Supp. 1, 1959).

The appropriate sentence of the statutes relating to temporary and definitive loans, 5 I02(a),

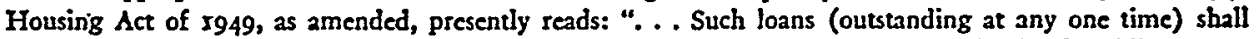
be in such amounts not exceeding the estimated expenditures to be made by the local public agency for such purposes, bear interest at such rate (not less than the applicable going Federal rate), be secured in such manner and be repaid in such period (not exceeding, in the case of definitive loans, forty years. from the date of the bonds or other obligations evidencing such loans), as may be deemed advisable by the Administrator." (Emphasis added.) 63 Stat. 414, 2s amended, 73 Stat. 654 (1959), 42 U.S.C. j 1452 (a) (Supp. I, 1959).

Section 102 (c) of the Housing Act of 1949, as amended by 5402 (b) of the Housing Act of 1959 . added "the principal of and the interest on," and this section presently provides:

"(c) Loans made pursuant to subsection (a) or (b) hereof may be made subject to the condition that, if at any time or times or for any period or periods during the life of the loan contract the local public agency can obtain loan funds from sourees other than the Federal Government at interest rates lower than: 
tate a determination of congressional intent by inferences which involve rather practical considerations.

Section $105(a)^{4}$ directs that the act be administered to "afford maximum opportunity ... for the rehabilitation or redevelopment of the urban area by private enterprise." Since municipal ownership of the redevelopment area does not afford private enterprise as much opportunity for participation in the redevelopment as does private ownership, adoption of municipal ownership as a goal, rather than a sometimes necessary incident of urban renewal, is contrary to the expressed intent of the act.

\section{I}

\section{Categorizs of Leases}

In the disposition of urban renewal project land, leases can be generally categorized in three main groups: ( 1 ) the "lease-purchase," in which provision is made for transfer of title to the lessee at the end of the lease term; (2) the lease with option to purchase; and (3) the straight-term lease.

\section{A. Lease-Purchase}

The first type of lease, although couched in language which is commonly used in a lease, has the same effect as an installment sale. Title is transferred at the termination of the "lease" term, without the necessity of payments other than those already paid as rent. The sum total of the rental payments equals the amount it would take to pay off a mortgage for the full purchase price at the going interest rate. The equivalent of a prepayment clause in a mortgage is provided by an option for the lessee to prepay the rental at a discount and take title prior to the lease tèrmination date.

Title I spells out neither a prohibition against installment sales nor a requirement that sales be made only for cash. However, from statutory provisions relating to the types of land disposition, ascertainment of net project costs, ${ }^{6}$ and definitive

provided in the loan contract, it may do so with the consent of the Administrator at such times and for such periods without waiving or surrendering any rights to loan funds under the contract for the remainder of the life of such contract, and, in any case, the Administrator is authorized to conisent to a pledge by the local public agency of the loan contract, and any or all of its rights thereunder, as security for the repayment of the principal of and the interest on the loan funds so obtained from other sources." (Emphasis added.) 63 Stat. 414, as amended, 73 Stat. 654, 42 U.S.C. 1452 (c) (Supp. I, 1959).

A definitive loan was made in connection with a lease from the Redevelopment Authority of Pittsburgh to the Public Auditorium Authority of Pittsburgh in the Lower Hill Project, U.R. Pa. 7-r, Pittsburgh, $\mathrm{Pa}$. The definitive loan was completed on Dec. 9, 1958, prior to the legislative changes noted above, which were approved by Congress on Sept. 23, 1959.

- Section ros(a) of the Housing Act of 1949, as amended, provides that:

"(a) The urban renewal plan for the urban renewal area be approved by the governing body of the locality in which the project is situated, and that such approval include findings by the governing body that ... (ii) the urban renewal plan will afford maximum opportunity, consistent with the sound needs of the locality as a whole, for the rehabilitation or redevelopment of the urban renewal area by private enterprise ...." 63 Stat. 416, as amended, 70 Stat. 1097 (1956), 42 U.S.C. 5 I455(a) (1958).

"See note I supra.

- Provision is made for net project costs in $110(f)$ of the Housing Act of 1949, as amended:

"(f) 'Net project cost' shall niean the difference between the gross project cost and the aggregate 
loans, ${ }^{7}$ the Urban Renewal Administration (URA) has inferred that the account between a local public agency (LPA) and URA cannot be settled and closed out unless the sales proceeds have been received from the purchaser in cash or, in the case of lease, from the proceeds of a definitive loan. As a consequence, installment sales have not been permitted. ${ }^{8}$

If this rule were applied consistently, the federal government would be denied participation in any receipts generated by an LPA after the account had been settled. Among the things whose infinite variety time seems not to wither are the commercial transactions of free men; and it is beginning to be apparent that the broad range of redevelopment endeavor will produce situations in which any such rule would be ill advised.

The legal necessity, as well as the administrative advisability, of an unqualified prohibition against installment sales seems questionable. A project involving leased property is closed out ${ }^{10}$ only with funds loaned or guaranteed by the federal government, the loan to be repaid from lease proceeds. No discernible legal or practical purpose is served by making a loan to $A$, with the understanding that the loan is to be repaid by $B$, in order to avoid having $B$ owe the money in the first place. Subject, of course, to proper administrative regulation, the installment sale should be recognized as one of the disposition techniques available for urban redevelopment. The lease-purchase, which exists only as an ersatz installment sale, would then no longer have a reason to exist.

\section{B. Lease with Option to Purchase}

The lease with an option to purchase, like the lease-purchase, is primarily a financing device. Institutions loaning on leaseholds have a strong preference for an option either for perpetual renewal or for purchase. The Federal Housing Administration (FHA) unqualifiedly requires an option to purchase running to it in the event of default by the mortgagor-lessee. The rental is usually an expression of the capital value of the fee simple in terms of an annual percentage-which probably is a little higher than the rate for good first mortgages (because it is determined in an atmosphere of enterprising rather than lending) and lower than the rate for second

of ( $x$ ) the total sales prices of all land or other property sold, and (2) the total capital values (i) im. puted, on a basis approved by the Adninistrator, to all land or other property leased ...." 63 Stat. 420, 25 amended, 7 I Stat. 300, 42 U.S.C. 51460 (f) (1958).

${ }^{2}$ Section $102(2)$ of the Housing Act of 1949, as amended, 63 Stat. 414,70 Stat. 1097 (1956), 42 U.S.C. 1452 (2) (1958).

Information from URA indicates that there have not been any installment sales of project land.

- For example, a redeveloper offered to purchase land from an LPA and in addition to payment of the purchase price at time of transfer, the redeveloper would later make additional payments. The additional payments to the LPA subsequent to the project being closed out would be in the nature of gratuitous payments and, therefore, it would seem that the federal government would not, in effect, be entitled to receive any of the proceeds from such additional payments. Of course, the URA did not approve such a transaction.

${ }^{10}$ See note 3 stepra. To date, the only completed definitive loan transaction is in connection with the lease in the Lower Hill Project, U.R. Pa. 7-1, Pittsburgh, $\mathrm{Pa}$. This project has not been closed out because some project land has not been disposed of. 
mortgages (because, in fact, the lease with an option is a security device senior to the "first" mortgage).

When parties have negotiated an option figure reasonably related to the value of the land, it would evidence a rare circumstance or a sadly deflated project if the option were not ultimately exercised. The financing provided by so deferring actual purchase is one hundred per cent of the price of the land. However, whatever may be the advantages of this financing to the redeveloper, they are not without offsetting disadvantages. A conventional loan will not include the land value in the mortgage base, so that the investment saving of the redeveloper is reduced by that portion of the land value on which he could borrow if he owned the land. Further, the lender who realizes that he may have to redeem the fee simple in self-protection may deduct the rest of the land-cost from the loan as insurance against such an eventuality. An FHA loan is computed by deducting the value of the fee interest in the land alone from the mortgage amount (not the appraised value) which would be insured on the improved fee. In FHA cases, this method of computation will always precisely offset any financing advantage from leasing, except in cases where the value of the unimproved land is so high in relation to the maximum FHA insurable mortgage that it over-offsets the advantage. ${ }^{11}$

Notwithstanding all this, there is still a substantial demand among redevelopers for leases with options. This proves at least that there is no limit to human ingenuity, and no doubt there will always be some constructive use for such leases. On the whole, however, it cannot yet be determined how closely the demand for such leases equates with the good of the program, and how much the demand is related simply to the versatility of such leases as vehicles for speculation in urban renewal.

The lease with option presents an obvious means to obtain a short-term option in circumvention of the existing rule against options. If options were permitted, as such, there would no doubt be fewer demands to accompany the option with lease provisions. On the other hand, the lease portion carries with it settled rights which may permit more development work pending exercise of the option than would an installment contract or pure option-particularly since unexpected events might prevent the exercise of the option for a considerable period of time after redevelopment had begun.

Even when an option in a lease is intended for early exercise, an LPA would be imprudent if it did not plan definitive financing when it makes such a lease. If there is good reason to expect early exercise of the option, the definitive financing should be postponed and the lease carried by temporary financing until the option has either been exercised or its exercise postponed for a period of time sufficient to support marketing of the loan.

\footnotetext{
${ }^{21}$ Assuming that the maximum insurable mortgage amount in case of fee ownership is $\$ 1,000,000$, and the capitalized ground rent is $\$ 100,000$, the total maximum insurable mortgage amount which the FHA will loan on a leasehold is $\$ 900,000$. However, if the property werc owned in fee, the FHA would loan the total maximum insurable mortgage amount of $\$ 1,000,000$.
} 


\section{Straight Lease}

The third type of lease is just that and no more. It is not accompanicd by an option either for purchase or perpetual renewal. Fundamentally and philosophically it differs from the other two types of leases wherein the lease provisions merely assist in accomplishing the principal purpose of transferring title. The straight lease provides for reversion of the improvements to the local authority, generally without cost, as well as retention of the fee interest. Leasing has been urged as one of the major tools of urban renewal. ${ }^{12}$ An obvious by-product of straight leasing is permanent municipal ownership of the urban real estate involved. Equally obviously, therefore, this inevitable incident of leasing was not intended to prevent leasing in an appropriate case. However, advocates of straight leasing recognize municipal ownership not as a by-product, but as a goal. ${ }^{13}$ They claim that it eases the administration of controls and regulations and the enforcement of municipal ordinances, eliminates the difficulties attending future reassembly of the same property, and preserves for the public instead of private individuals the benefit from appreciation in property values. ${ }^{14}$

To the extent that these reasons are valid, their application is not limited to urban renewal real estate. If these considerations are controlling, or if they constitute a public purpose sufficient to support drastic interference by public power and resources with the ownership of private property, one of the big surprises in the urban renewal package might well be a return to feudal land tenure.

Several articles which advocate downtown municipal ownership of real estate have appeared in the Journal of Housing. ${ }^{15}$ A comment in the Yale Law Journal which strongly advocates widespread leasing of urban renewal land frankly acknowledges that such a program would eventually lead to municipal ownership of land from the proceeds of federal subsidies. Among the examples cited as evidence of the soundness of municipal ownership is the system of land tenure in several European cities, including some in Great Britain. ${ }^{16}$ The philosophical foundation of at least some of these references is clear; the British studies relied on there bear the stamp of Fabian socialism. ${ }^{17}$

On a case-by-case basis, it must be recognized that there are situations where the advisability of leasing as opposed to sale is so strong as to amount to necessity.

19 See Comment, Long-Term Leasing in Urban Renewal: An Alternative Method of Municipal Land Disposition, 68 YALE L. J. I424 (1958); Raymond, Successful Rehabilitation Calls for New Approach: Continuous Renewal, i7 J. Housısc 135 (1960); see also comments by John R. Searles, Jr., Executive Director, District of Columbia Redevelopment Land Agency, in Searles, Continuous Renewal: Here is What Others Say About It, I7 J. Housing 191 (1960); see also statements made by Lawrence M. Cox, Executive Director, Norfolk Redevelopment and Housing Authority, Norfolk, Va., in an address to the American Society of Planning Officials at its 1960 Convention in Miami Beach, Fla., May 22, 1960.

${ }^{12}$ See Raymond, supra note 12; Cox, supra note 12.

14 See Comment, Long-Term Leasing in Urban Renewal: An Alternative Method of Municipal Land Disposition, 68 YALE L. J. I424 (1958).

${ }^{15}$ See Raymond, supra note 12; Searles, supra note 12.

10 See Comment, Long-Term Leasing in Urban Renewal: An Atternative Method of Municipal Land Disperition, 68 YALE L. J. 1424 (1958).

${ }^{2 T}$ Id. at 1426 . 
For example, continued government ownership of key waterfront property was recognized as being of such importance that Congress authorized the transfer of certain government property to the District of Columbia Redevelopment Land Agency for leasing only. ${ }^{18}$ However, such cases are justified by unique factual situations rather than the application of doctrines favoring leasing as an instrument to effect municipal ownership of urban real estate.

Notwithstanding the occasional emergence on the local scene of dominant socialist governments, no political party or leader has ever suggested seriously to the local electorate a program for using public funds to acquire urban real estate in order that controls, regulations, and ordinances might be administered as a landlord rather than as a governing body, in order that problems attending possible future assembling of property might be anticipated, and in order to make a profit for the governmental unit from the appreciation of the property so acquired. Those who seriously advocate such a program now in the name of urban renewal are able to do so without presenting it to any electorate because of the several federal subsidies built into the leasing process.

First of all, the LPA, in effect, buys the property with the proceeds of a loan either made by the federal government or, if the loan is obtained in the private investment field, guaranteed by the federal government. The interest rate of the private loan is low because the federal government guarantees the lender both his principal and his interest. ${ }^{19}$ It is low also because the proceeds to the lender are exempt from federal taxation. ${ }^{20}$ The LPA then leases the property at a rate which is set in the marketplace by lessors who, among other things, pay income taxes. On the other hand, the proceeds of the lease when received by the LPA are not subject to income taxation. There has not been, and will not likely be, a time when the differential between the interest paid by the LPA and the tax-free rents received by it will not pay off the definitive loan in a period of time considerably shorter than its maximum term. As the result of the three separate federal contributions to the leasing process, the local political entity can acquire leased urban renewal land without substantial, if any, cost to itself.

The power of government to superimpose upon private ownership very considerable controls over the use and condition of land has been increasingly recognized. The principal, if not the only, justification for government interposition in the chain of title of urban renewal real estate is the need to use the power of eminent domain. Weighing such factors as the language in the Housing Act, which makes repeated references to development by private enterprise, it seems obvious that Congress assumed this interposition would be of short duration and did not intend the urban renewal program to foster municipal ownership of downtown and other urban renewal real estate. The lease should be used only when urban renewal land cannot be disposed of by sale.

\footnotetext{
-Act of Sept. 8, 1960, 74 Stat. 871.

1863 Stat. 414 (1949), 70 Stat. 1097 (1956), 42 U.S.C. 1452 (c) (1958).

${ }^{20} 63$ Stat. 414 (1949). 70 Stat. 1097 (1956), 42 U.S.C. $\$ 145=(g)(1958)$.
} 
The urban renewal plan was conceived as the appropriate method of making provisions for controls and restrictions, which would then be enforced by the appropriate governmental body. The assumption is that controls and restrictions, as well as local building codes, zoning ordinances, and so forth, can be effectively administered and enforced. If, as the leasing advocates urge either implicitly or explicitly, local authorities can exercise necessary control only through municipal ownership, then of what benefit is the urban renewal plan, or, as a matter of fact, the whole urban renewal program, except to the extent it involves leasing? The logical inference of this line of reasoning would be that the concept of urban renewal can only succeed by complete public ownership of urban real estate.

It has been suggested that leasing will result in a greater return to the urban renewal disposition program by creating imputed capital values greater than the amount which would be received on outright sale. As a general principle, it does not seem reasonable that a man will pay, for example, eight per cent to rent something which he could buy with money borrowed at six per cent. This is an area in which facts may perhaps lend themselves to as many interpretations as there are interpreters, but our examination of available evidence indicates that the redevelopers tend to stay within the appraised value, whether the transaction is a lease or a sale, and, when they exceed the appraisal, this is not caused by the availability of the property by lease rather than by deed.

In connection with the subject of controls, it is our judgment that the program is already suffering from too many, not too few, controls. Instead of thinking in terms of expanding the scope and basis of municipal controls in the urban renewal program, it might be wrell to consider reducing, if not eliminating, many of the control standards which are imposed in addition to those set forth in the zoning, housing, and building codes. ${ }^{21}$

II

\section{Arrangements for Financing}

Closing out an urban renewal project involves a division of the net project cost between federal and local governments. ${ }^{22}$ In ascertaining the net cost, the proceeds from land sales are subtracted from gross project cost. ${ }^{23}$ When project land is retained by the LPA and leased, there are no sales proceeds to deduct. Instead, a capital value is "imputed"24 to the land, and in order to close out the project account,

${ }^{21}$ See Brownfeld, Disposition of Urban Renewval Project Lands, 25 LAw \& Contemp. ProB. 732 (1960).

${ }_{22} 63$ Stat. 416 (1949), 73 Sțat. 672, 42 U.S.C. 51453 (a) (Supp. I, 1959).

2s Scction $110(f)$ of the Housing Act of 1949, as amended, provides as follows:

"(f) 'Net project cost' shall mean the difference between the gross project cost and the aggregate of (x) the total sales prices of all land or other property sold ..." 63 Stat. 420, as amended, 71 Stat. 300 (1957), 42 U.S.C. \$ 1460 (f) (1958).

1i Section Iro(f) of the Housing Act of 1949, as amended, further provides for a deduction of "... (2) the total capital values (i) imputed on a basis approved by the Administrator, to all land or other property leased ..." from the gross project cost. 63 Stat. 420, as amended, 71 Stat. 300 (1957), 42 U.S.C. $\$ 1460(f)(1958)$. 
the LPA contributes this amount to the settlement from the proceeds of a "definitive" loan. ${ }^{25}$

The Housing Act also authorizes the Housing and Home Finance Agency (HHFA) to agree to make a forty-year loan and to permit the loan agreement to remain executory throughout the entire forty years. ${ }^{28}$ The act further authorizes the LPA to pledge the HHFA loan contract as security for its own borrowings from private sources. ${ }^{27}$ Bonds issued by LPAs for this purpose are exempt from federal income taxation. ${ }^{28}$

It is expected, therefore, that LPAs will in practice arrange permanent financing in the private market. The federal guarantee and tax exemption have worked throughout most of the urban renewal program to provide a private market for temporary financing at rates lower than those that attach to direct federal loans, and these same advantages are expected to attract private financing of the permanent loans covering leased land. ${ }^{20}$

URA has approved twenty-two requests by LPAs to lease land. All of these agreements carry with them either express or implied promises to make or guarantee the definitive or permanent loan necessary to enable the LPA to pay to URA the value imputed to the leased land. However, no project involving a lease has yet been closed out, and only one lease transaction has been completed through the definitive loan stage. ${ }^{30}$ In some instances, LPAs have continued temporary financing to carry the investment in land under lease, and in still other cases, the leases have not yet actually been executed.

The right of a lessee to acquire clear title to the leased premises, whether expressed as an option or as a right to prepay a lease-purchase, counters the desire

${ }^{25}$ Section $102(a)$ of the Housing Act of 1949, as amended, 63 Stat. 4r4, as amended, 73 Stat. 654, 42 U.S.C. $\$$ ז452(a) (Supp. 1959).

"Section I02(a) of the Housing Act of 1949, as amended, provides that ". . . Such loans (outstanding at any one time) shall be in such amount not exceeding the estimated expenditures to be made by the Local Public Agency for such purposes, bear interest at such rate (not less than the applicable going Federal rate), be secured in such manner, and be repaid within such period (not exceeding, in the case of definitive loans, $4^{\circ}$ years from the date of the bonds or other obligations evidencing such loans), as may be deemed advisable by the Administrator." 63 Stat. 414, as amended, 73 Stat. 654, 42 "U.S.C. 5 I452(a) (Supp. 1959).

${ }^{27} 63$ Stat. 416 (1949), 70 Stat. 1097 (1956), 42 U.S.C. $\$ 1452$ (c) (1958).

2* See note 20 supra.

${ }^{29}$ If the LPA can obtain private financing at lower interest rates, 5 r02(c) of the Housing Act of 1949, as amended, authorizes the Administrator "to consent to a pledge by the Local Public Agency of the loan contract, and any or all of its rights thereunder, as security for the repayment of the principal of and the interest on the loan funds so obtained from other sources." 63 Stat. 414, as amended, 73 Stat. 654, 42 U.S.C. 5 1452(c) (Supp. I, 1959).

The federal guarantee is evidenced by a requisition agreement by which the federal government agrees to make a loan to the LPA sufficient to pay the principal of and interest to maturity on the bonds. Provision for interest rates on Title I loans and advances applicable to contracts authorized is contained in Urban Renewal Manual, 5 17-6-8, as amended by Local Public Agency Letter No. 201.

30 See note 10 supra. The lease from the Urban Redevelopment Authority of Pittsburgh, Pa., to the Public Auditorium Authority of, Pittsburgh and Alleghany County is for 2 term of 45 years. It provides for a lease-purchase arrangement in that the lessee is given an irrevocable option during the term of the lease after construction and improvements to have delivered a deed for the property, provided that the lessee has paid the rentals and charges due under the terms of the lease. 
of bond purchasers for a guaranteed minimum period of investment and the necessity of paying a premium upon redemption of the bonds. It should be noted that these two counter forces are not equivalent. Notwithstanding the customary payment of a premium for redemption, the bond buyer still wants assurance of some substantial period of investment. A premium sufficient to attract buyers for bonds subject to redemption in two years, for example, would be so high as to be prohibitive in practice. Educated guesses of men who participate in urban renewal financing and who will no doubt play a large part in marketing definitive bonds are that a minimum period of approximately fifteen years will be needed to assure marketability of the bonds.

If a redeveloper wishes to acquire the property through the medium of an option in a lease, it is not difficult to conclude that he should pay any additional cost occasioned by this method of acquiring title. In other words, his option price should probably be increased by an amount sufficient to pay the redemption premium. But, in addition to this internal financial apportionment, the redeveloper and the LPA must apparently also phrase the purchase option so as to postpone its exercise until fifteen years oi more after the date of the definitive loan.

Although, as in the case of temporary financing, the federal guarantee and federal income tax exemption will be the two main attractions for the buyer of definitive bonds, the longer term and the existence of other interests in the land will make it necessary to add whatever other assurances may be available. Principal among these will be an assignment of the rents and, of course, the proceeds of any sale under the option. ${ }^{31}$

URA requires as a condition to the making or guarantee of a definitive loan that the rent be sufficient to pay off the loan in full within the terms of both loan and lease. The loans are limited by statute to forty years. ${ }^{32}$. Since they are being repaid entirely by the differential between lease income to the LPA and the interest charges paid by the LPA, loans will tend to be for the full legal term. The law places no limit on the length of the leases, but as a practical matter, the loan term will tend to be the minimum term for the lease.

The long-term bond market differs materially from the short-term market in which urban renewal temporary loan notes are marketed. The implications of this difference are important to the LPA, if not to the federal government, because of the irretrievability of mistakes which may be reflected in the effective interest rate. One consideration of vital importance is the dollar amount of bonds made available to the market at one time. In order to do the kind of a job necessary to get a good

\footnotetext{
21 Section $102(2)$ of the Housing Act of 1949 , as amended, provides that the loan shall be "secured in such manner . . . as may be deemed advisable by the Administrator." 63 Stat. 414 , as amended, 73 Stat. 654, 42 U.S.C. 5 1452(a) (Supp. 1, 1959).

In the definitive loan which was made pursuant to the lease to the municipal auditorium in the Lower Hill Project, U. R. Pa. 7-1, the bonds were given an exclusive first lien upon and 2 pledge of the income and proceeds derived from the lease. The city and county also $\mathfrak{E}$ taranteed tental payments under the lease.

${ }^{20}$ See note 7 supra.
} 
market, one bond house has estimated in private discussions that around $\$ 25$ million should be the minimum amount of bonds to be marketed at one time. Since it will take a number of different lease situations to produce $\$ 25$ million of definitive financing, and because of the other considerations just mentioned, it will be necessary for the Washington office of URA to exercise a degree of active control, supervision, and coordination over definitive financing different from and greater than that experienced in temporary financing.

Important as the federal guarantee is, and will be, to the marketing of temporary loan notes and definitive bonds, this guarantee is expressed by indirection. ${ }^{33}$ The result is to complicate such financing unnecessarily, adding to the work and expense required of outside bond counsel and to the administrative processing and lapse of time in both the LPA and URA. An unequivocal, incontestable guarantce by the federal government, simply and directly expressed on the note, bond, or accompanying instrument would eliminate unnecessary processing, expense, and delay. No doubt one reason for the indirect expression of the guarantee has been a desire to avoid problems relating to the statutory debt limit. However, it seems possible to draft legislation eliminating the one set of problems without creating the other. There would be dollars of benefits to the temporary financing program for every penny saved in connection with definitive loans, and any such happy, everybody-winsnobody-loses development (except for bond counsel, whose patriotism should certainly be equal to the test) should find bipartisan support in Congress.

\section{III}

\section{IMPUTED VAIUE}

The Housing Act does not define a method for determining the value which is imputed to leased land as a substitute for sales proceeds. In the absence of some definitive interpretative guide, a priori reasoning suggests the imputed value is intended to approximate actual value to the LPA as closely as the imperfect process of hypothetical evaluation will allow. The final determination, which is subject to acceptance by both the URA and the LPA, is complicated by the fact that the interests of the LPA and the federal government are divergent under procedures hitherto in force.

Whatever influence the imputed value may, as a practical matter, have on the substance of the transaction, it is legally significant only in the settlement of accounts between the LPA and the URA. It need not be a factor in the leasing and financing arrangements. The LPA may battle for high rents, high option price, and low financing costs without committing itself to any figure as representing the value of the property for the purpose of settling with the URA. Obviously, it is to the benefit of the LPA to keep the imputed value as low as possible."

s2 See note 29 supra.

24 The imputed value is subtracted from the gross project cost to arrive at the net project cost, upon which the $3 \frac{1}{3} \frac{1}{3}$ division is based. The rentals received by the LPA over and above the imputed value and the loan cost are retained by the IPA and are not used to reduce net project cost. 
Leases designed as vehicles for the ultimate transfer of title contain explicit indications of the value to the lessee-purchaser. The lease with an option contains a dollar figure. The commuted value of the payments under a lease-purchase can be easily calculated by using the going rate of interest at the time the deal was negotiated. But if these figures are used, another question arises. During the lease interval prior to transfer of title there will be a profit resulting from the differential between lease and interest rates and from the tax-exempt character of the LPA. To whom does this profit belong?

Regardless of their language, the substance of these leases is a delayed sale. If such a postponed sale had been consummated after a period of interim use producing the same profit, the money would have gone to reduce project cost and would thereby have been shared by the LPA and the URA. When the sale is disguised as a lease, unless the prospect of this profit is taken into account in value imputed to the leased premises, the entire profic (which results solely from federal guarantees and tax forbearances) will be realized by the LPA.

Although nothing in the Housing Act expressly forbids installment sales, options, or delayed sales, neither is there any permissive language indicating that such transactions might be so designed as to confer an interim profit to the LPA which would not be accountable as project income. It is reasonable to conclude that income not susceptible of diversion from a delayed sale may not be diverted by employing lease language.

The intent of the statute can be served and a divergence in the interests of the LPA and the URA can be avoided by taking this incidental profit into account in determining the imputed value. Considering the abstract quality of the value imputed to the land-and since the act deals in terms of fair value, not fair market value $^{35}$ - this value should be the value to the LPA, taking into consideration the surrounding circumstances, which include the existence of the profit under discussion. If the imputed value is taken as the option or purchase price increased by the profit incidental to the delay, the LPA and the URA will share in such profit in the same proportion as they share in other project income; the divergence of their interests disappears and the basic intent of the Housing Act for apportioning urban renewal costs is served.

The same principle can be applied with approximately the same results in the case of land subject to straight lease. The considerations restricting leasing to project land not marketable by sale have already been discussed. It has been mentioned earlier that ( $\mathrm{I}$ ) congressional emphasis of maximum participation of private enterprise in redevelopment precludes leasing as a method of disposition except when sale on reasonable terms is impossible; and (2) when urban renewal land is leased, the Housing Act recognizes that permanent public ownership of the land will result. A third necessary implication of the statutory provision for a forty-year loan to finance the leasing ${ }^{36}$ is that the federal share of the cost of the land so transferred

\footnotetext{
${ }^{88}$ See note I supra.
}

${ }^{86}$ See note 26 supra. 
to permanent local public ownership will be repaid from the lease proceeds, which necessarily means from the differential between net financing cost and the net return on the lease, a differential created by the federal guarantces and tax exemptions mentioned earlier. But should this subsidy be subject to expansion by force of circumstance or clever negotiation? In the long run, every policy or interpretation which forces the interests of the LPA and the URA into conflicting rather than coinciding patterns will be detrimental to successful urban renewal. The value imputed to leased land should take into account both the lease income and the financing costs to the LPA and be so computed that the income differential (over and above financing costs to the LPA) for the statutory forty-year loan term would equal the imputed value precisely. ${ }^{37}$

The conclusion is inescapable that the unresolved questions of "whether" and "whither" have retarded the development of answers to a third question, "how"in the field of urban renewal leasing. The early resolution of the first two questions along the lines proposed in this article will bencfit urban renewal, and is a worthwhile goal. However, the present existence of leasing commitments which must be completed, whether or not they should have been made in the first place, and the statutory provision for leasing as a means of disposition in appropriate cases indicate that one of the next major developments in the urban renewal technique will be a set of complete answers to the "how" of leasing, regardless of long-term developments with respect to "whether" and "whither."

87 The situation to which this suggestion is directed, and the widely divergent results produced by the alternate approaches, is illustrated by the following projection based upon an actual lease by an LPA:

FACTS: The direct acquisition cost of the property was \$r94,452.42. Bids were takcn on a 35-year lease, annual rental to be $6 \%$ of value bid. Successful bid, \$20x,000. Annual rental, \$12,060.00. Financing rate called for in loan contract with URA, 2.76\%. Taxes to be paid by lesser. For ease of calculation, single annual rent payments assumed.

ALTERNATE RESULTS: (I) If the value imputed to the leased property is $\$ 201,000,35$ annual payments of $\$ 8722.44$ will service and retire the debt. The LPA realizes an annual profit of $\$ 3327.56$ during the 35 -year lease term, a total of $\$ 116,464.60$, or the application of the full annual rental to amortization of the loan would service and retire the debt in approximately 22 years. The subsequent annual rentals belonging solely to the LPA would grosi $\$ 136,780$ over the balance of the leaso term. The profit to the LPA in either case substantially cxceeds the LPA's $1 / 3$ contribution to the acquisition cost.

(2) The annual rental of $\$ 12,060$ would service and retire a 35 -year loan of $\$ 268,857.68$. If a value were imputed to the leased property equal to the price which its own rentals would pay during the lease term, project proceeds would be increased by $\$ 67,857.68$. Net project cost would be corre spondingly decreased, to the benefit of federal and local governments in their contributing proportions.

In both alternatives, the figures are based on unencumbered ownership of the fee by the LPA at the end of 35 years, 5 years less than the maximum loan period set by statute.

Since the lease must be at least as long as the loan term, and the relationship between rentals and imputed value must be such that the rentals will completely service and retire the loan, if alternative (2) is adopted but the lease-loan term is left open for negotiation, the same divergence between IPA and URA interests will appear in determining the length of the term. This conflict can be avoided if the calculation is always done on the basis of a 40 -year term. 